\title{
Recharge and drainage of lakes in the Powidzki Landscape Park in conditions of increased anthropogenic and environmental pressure (central-western Poland)
}

\author{
Bogumił NOWAK ${ }^{1, *}$ and Jan PRZYBYŁEK ${ }^{2}$ \\ 1 Institute of Meteorology and Water Management - National Research Institute, Podleśna 61, 01-673 Warszawa, Poland \\ 2 Adam Mickiewicz University, Institute of Geology, Krygowskiego 12, 60-680 Poznań, Poland
}

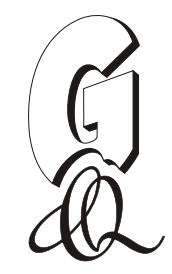

Nowak, B., Przybyłek, J., 2020. Recharge and drainage of lakes in the Powidzki Landscape Park in conditions of increased anthropogenic and environmental pressure (central-western Poland). Geological Quarterly, 64 (1): 205-219, doi: $10.7306 /$ gq. 1524

Associate Editor: Tatiana Solovey

The lakes of the Powidzki Landscape Park (Gniezno Lakeland) are known for their natural and recreational values. The majority of them are located within two large glacial tunnel valleys, that in many places cut through several levels of till and inter-till aquifers. Regional hydraulic linkage systems are developed where surface water and groundwater remain in direct contact. Smaller water bodies occur between the lakes, in other tunnel valleys, in isolated meltwater basins, or in river valleys. These water bodies constitute local drainage bases. The existence in the area of such morphologically diverse lakes with different flow rates, varied morphology, and heterogeneous geological structure permitted tracing of the hydrodynamic dependencies of lake catchments of various types. Hydrogeological cross-sections, comparative analyses of structural maps for successive aquifers, bathymetric plans of lakes, and piezometric contour maps were prepared. Surface and groundwater level fluctuations were investigated, as well as their response to changing atmospheric conditions. Water balances of lakes were also determined for selected lake catchments. The study showed that all the lakes analysed are closely related to groundwater, and that the deepest ones reach lower aquifers. The majority of the lakes drain the aquifers, but some of the lakes feed them. Such a situation was documented in coastal wetlands and in the eastern part of the Park, affected by a depression cone associated with a nearby lignite opencast mine. The study showed that the deepest of the lakes analysed have a very wide catchment area of groundwater recharge, expanding beyond the boundaries of their surface catchment areas. This is important for the development of their resources, especially in periods of hydrogeological low flow.

Key words: surface and groundwater resources, hydraulic contacts, water level changes, mining dewatering, evapotranspiration, Gniezno Lakeland.

\section{INTRODUCTION}

Unconfined groundwater circulation zones in lake catchments are still poorly investigated in Poland. Hydrological literature includes publications based on hydrological and meteorological data, omitting studies of the influence of the subterranean zone on the recharge and drainage of lakes (Mikulski, 1970; Pasławski and Błaszczyk, 1970; Bajkiewicz-Grabowska, 1982, 2002; Rösler and Chmal, 2008; Dąbrowski, 2013). Most authors describe the groundwater component in water balances of lakes based on hydrological and meteorological data, and most publications focus on single water bodies. In many publications, the interaction of lakes and groundwater is defined

\footnotetext{
* Corresponding author, e-mail: rugosa@op.pl
}

Received: April 4, 2019; accepted: January 13, 2020; first published online: April 2, 2020 based on water balances measured for the lakes, and the direction of groundwater flow in the area of lake bowls is determined by recharge and drainage. The studies often cover the entire year, sometimes resulting in erroneous determination of surface water and groundwater circulation patterns in lake catchments. Particularly in the case of deep lakes, draining several aquifers, conclusions drawn from such calculations may deviate significantly from reality. For example, in many cases, calculating recharge and drainage for an aquifer may give a positive value, providing information only on the inflow of groundwater. In reality, groundwater recharge may potentially prevail in one part of the lake, while in the other part water outflow to the aquifer is dominant. Moreover, this situation may change during extreme hydrological phenomena such as hydrological droughts or floods. Particularly in the case of long-lasting lowwater periods, the lake's water table may prove to be primarily regulated by the regional groundwater circulatory system (Nowak and Przybyłek, 2008; Przybyłek and Nowak, 2011; Nowak, 2018). Few Polish publications are available concerning the hydrogeological schematisation or hydrodynamic re- 
search covering the analysis of interactions between lakes and the surrounding aquifers (Krygowski, 1954; Pasławski, 1975; Dąbrowski, 1990; Kilkus, 1998; Glazik and Gierszewski, 2001; Burchardt and Przybyłek, 2004; Pomianowska, 2004; Krawiec and Śmietański, 2007; Nowak and Przybyłek, 2008; Nowak, 2018). These works show a significantly more complex character of hydraulic connections of lakes with the surrounding groundwater. Similar trends are observed in the global literature (Brock et al., 1982; Cheng and Anderson, 1993; Sacks et al., 1998; Shaw et al., 2013; Rautio and Korkka-Niemi, 2015; Rudnicki et al., 2015; Su et al., 2016).

Research on the interaction between lakes and groundwater and processes of their recharge and drainage requires interdisciplinary analysis combining hydrological, hydrogeological, and meteorological data. It is particularly important in areas under strong anthropogenic pressure and serious disturbance of local or regional aquifer systems.

This article shows the relationships between lakes and groundwater in the shallow and deep circulatory systems of the Powidzki Landscape Park in the Gniezno Lakeland. It concerns many lakes of different morphology, for which there is a dense measurement and observation network providing longterm meteorological, hydrological, and hydrogeological data. It was possible to study how these relationships changed over the years under the influence of various environmental factors, including the observed deterioration of climatic conditions (Kędziora, 2008; Przybyłek and Nowak, 2011; Nowak, 2018; Nowak et al., 2018; Nowak and Ptak, 2019). Various forms of human activity (mining, groundwater abstraction, water transfers out of the catchment area, water storage) that have affected water resources in the region provided the opportunity to establish to what extent anthropogenic pressure affects lakes and the connected groundwater. Such research is particularly important for the area studied, where a significant decline of lake water levels has been observed for years (IInicki, 1996; Ilnicki and Orłowski, 2006; Przybyłek and Nowak, 2011; Nowak, 2018).

The primary objective of this study was to determine the hydraulic interaction between lakes and groundwater in the Powidzki Landscape Park, and to indicate how this affects the water resources. An important aspect of the study was to indicate the environmental and anthropogenic factors affecting this interaction, and to determine its range in time and space.

\section{STUDY AREA}

The study area covers lakes and their catchments in the Powidzki Landscape Park in the central part of the Gniezno Lakeland (central-western Poland) (Fig. 1). The area is exceptional due to the occurrence of lakes with various morphometries and recharge types (Przybyłek and Nowak, 2011; Nowak, 2018), and its high variability in terms of geomorphology, surface lithology, and land use. The land relief is primarily developed by end moraines, running from the north-west to south-east. They act as a divide for surface water, and as a recharge zone for groundwater in this part of the Lakeland. Other outstanding landscape elements include north-south-oriented tunnel valleys with lakes, and valleys of draining rivers. They are grouped into three systems of surface drainage: southern with water flowing through the Meszna River to the Warta River, north-west - connected with the Noteć Zachodnia River, and north-east, including the Ostrowo-Gopło Canal.
The varied geological structure provides for the occurrence of several aquifers (Figs. 2 and 3 ) in the active groundwater exchange zone (Dąbrowski, 1990; Dąbrowski et al., 2011; Przybyłek and Nowak, 2011; Nowak, 2018). According to the hydrogeological classification (Paczyński and Sadurski, 2007), these are as follows:

- groundwater level of constant distribution, in a fluvio-glacial sedimentary aquifer with components of leached till and river sand. Over the area analysed, the groundwater table is in a range from 78.0 to $115.0 \mathrm{~m}$ a.s.l., and its shape corresponds with the land relief (Fig. 4);

- top inter-till level (first inter-till level), occurring over a major part of the terrain in sandy strata deposited between the north-Polish and Warta tills, in some places developing a hydrostructural unit along with the groundwater level. The distribution of hydroisohips of the top inter-till level corresponds with the first groundwater level, because they develop a single aggregated aquifer over a major part of the study area;

- middle inter-till level (second inter-till level), occurring as isolated layers of limited spread, connected with fluvio-glacial deposits occurring between the clays of the middle-Polish glaciations. The middle inter-till level shows a limited distribution, and no data on its water table are available;

- bottom inter-till and under-till levels, connected with sandy and gravel deposits of the Holstein Interglacial and fluvio-glacial successions of the Odra Glaciation. This level is called the Wielkopolska Buried Valley (wdk) because of the name of the regional hydrogeological structure. The flow of groundwater in this aquifer is to the east and south-east. The average stabilised water table of the wdk level is 95.0-105.0 m a.s.I. (Fig. 5);

- Miocene and Upper Cretaceous levels forming separate hydrostructural units (Gniezno-Inowrocław sub-reservoir) in the western part of the Park, and in the eastern part where they are hydrodynamically connected with the wdk level. The free-surface water table of the level is stabilised at 90-105 $\mathrm{m}$ a.s.l., largely corresponding to the distribution of the hydroisohips of the overlying wdk level.

Regional deep aquifers are exploited through numerous municipal water intakes and drilled wells operated by the nearby opencast mines of the Konin Brown Coal Mine (KWB Konin).

The area described area has very unfavourable hydro-meteorological conditions, including low precipitation and very high potential evaporation (Kędziora, 2008; Przybyłek and Nowak, 2011; Stachowski et al., 2016; Nowak, 2018, 2019; Nowak and Ptak, 2018). The region has very low drain rate values, not exceeding $3.0 \mathrm{l} /\left(\mathrm{s} \mathrm{km}^{2}\right)$ in the western part of the study area. Catchments in the eastern part of the area have been without outflow for years (Nowak, 2018). Since the beginning of the 1990s, in this part of the Gniezno Lakeland, significant water level declines have been observed in lakes (Fig. 6), as well as a reduction of groundwater resources and disappearance of wetlands (Ilnicki and Orłowki, 2006; Przybyłek and Nowak, 2011; Ilnicki et al., 2017; Nowak, 2018; Nowak et al., 2018).

The eastern part of the Gniezno Lakeland is located in a depression cone developed due to mining drainage (Przybyłek, 2011, 2018; Nowak, 2018). Another important factor is water management involving lake damming, groundwater intake exploitation, transfers of water from opencast mine drains and sewage treatment plants, and agricultural land reclamation (Przybyłek and Nowak, 2011; Nowak, 2018, 2019; Nowak et al. 2018; Nowak and Ptak, 2018). 


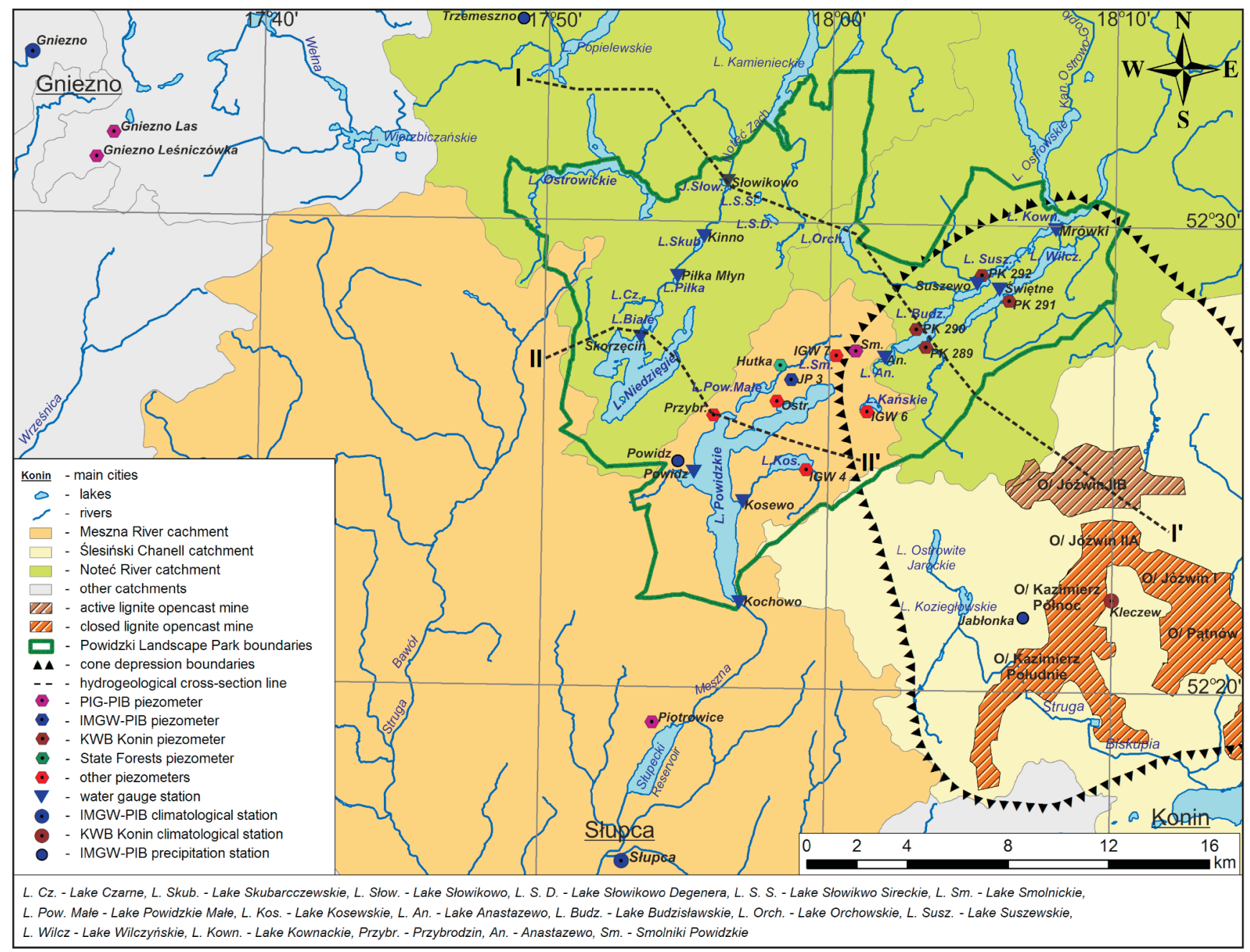

Fig. 1. Location of the study area and major measurement points used in the study

\section{MATERIALS AND METHODS}

Hydrogeological cross-sections and structural maps of each aquifer were prepared for the analysis of lake-groundwater interaction. The spatial image obtained was compared with compilations of groundwater tables and lake water levels, and with results from water balance calculations for selected lake catchments. The preparation of maps and cross-sections used some information from the Detailed Geological Map of Poland at a scale of 1:50,000 (sheets: Mogilno, Strzelno, Witkowo, Kleczew), data from borehole cards taken from the Central Hydrogeological Data Bank HYDRO, KWB Konin, and research conducted in the scope of the doctoral thesis of one of the authors (Nowak, 2018). Maps of geological structure were prepared with the application of ArcGIS 10.0 and CorelDraw X4. Information on groundwater fluctuations was obtained from the observation and measurement network of the Polish Geological Institute - National Research Institute (PIG-PIB), the Institute of Meteorology and Water Management - Polish Research Institute (IMGW-PIB), KWB Konin, and State Forests (LP). The observation sequences covered very different time periods for observation points, as shown in Figure 6 . The longest observation sequences covered the years 1976-2015, but most them covered the period 2002-2015. The data contained information on monthly groundwater levels (minimum, average, and maximum), based on mean daily values. Additional information on groundwater levels was obtained from the monitoring network, including piezometers and limnimetric wells. The paper also includes information on water levels from the doctoral thesis of Nowak (2018). Based on these data, piezometric contour maps were prepared. Due to the distribution of the aquifers and their importance for water supply to lakes, the study largely focused on the first aquifer, connected to all water bodies in the study area, and on the wdk aquifer, defining the location of the water table in deep lakes. For figures showing the distribution of hydroisohips in aquifers (Figs. 4 and 5) and the extent of the depression cone related to the nearby lignite opencast mine (Fig. 1), the averaged state for the year 2012 was selected, because in a multi-annual context it was an average year both in terms of precipitation and water table in the lakes or aquifers. 


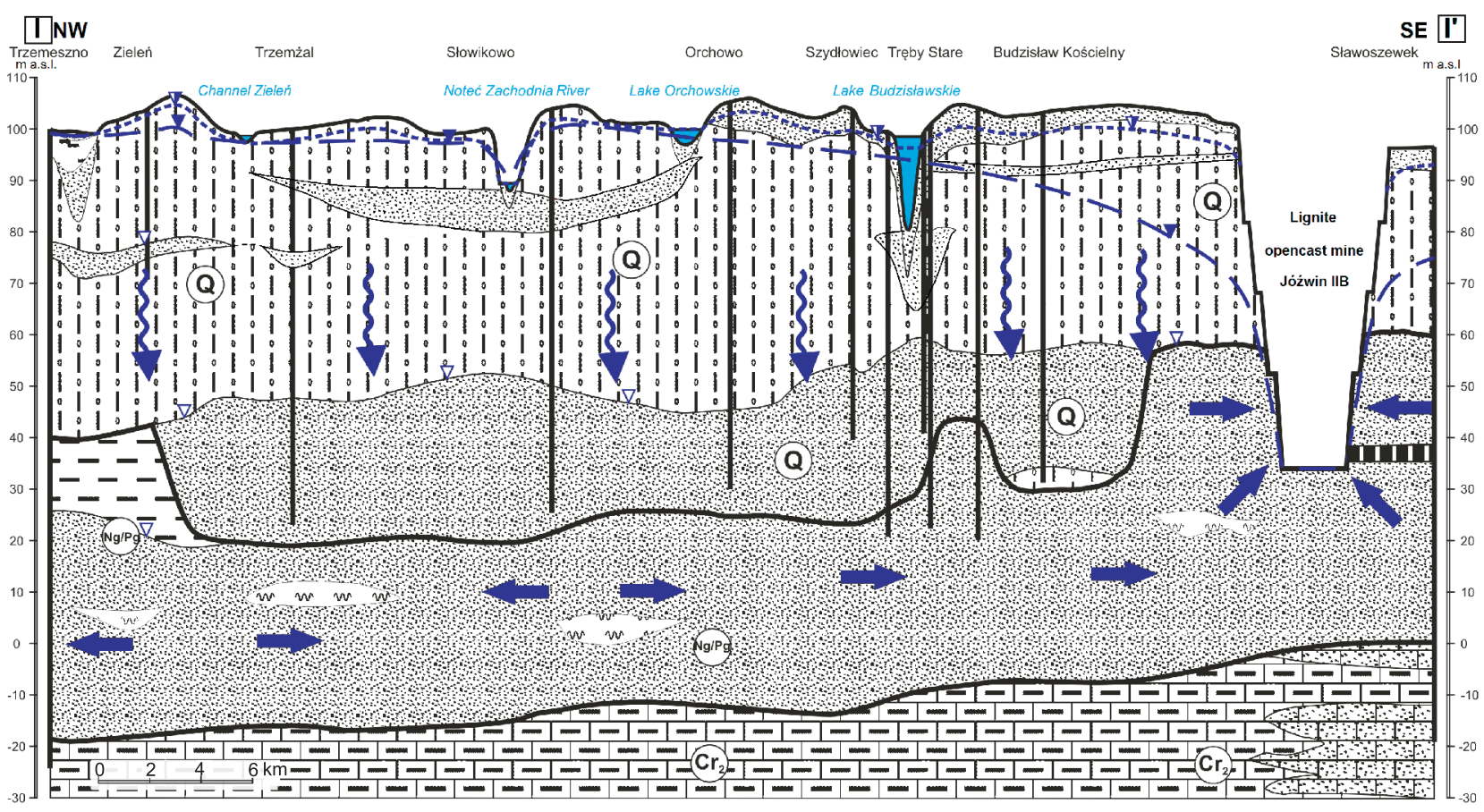

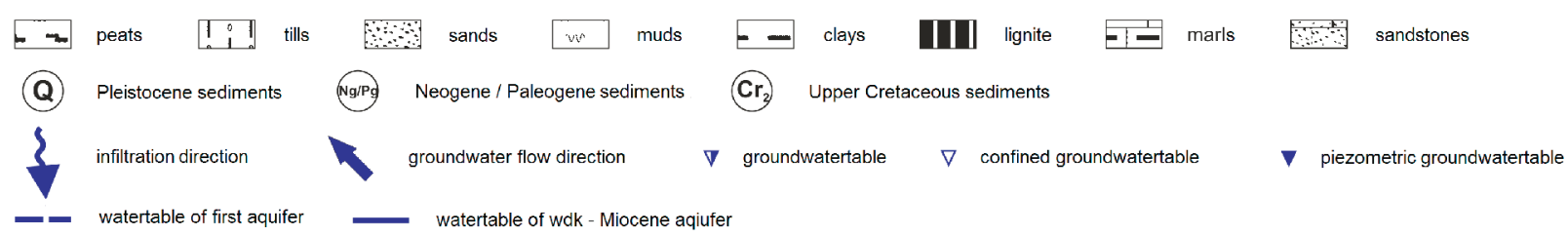

Fig. 2. Hydrogeological cross-section I-I'

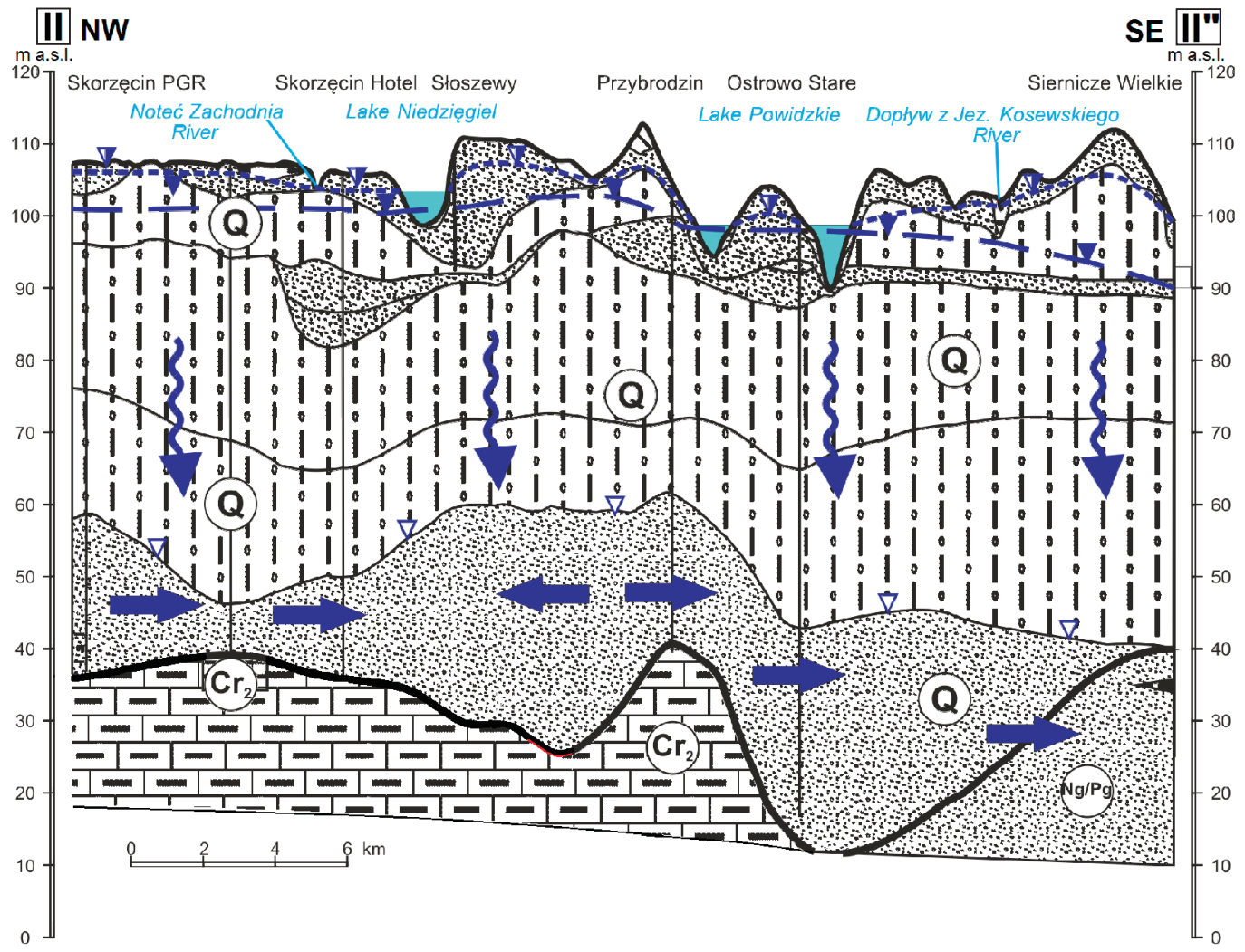

Fig. 3. Hydrogeological cross-section II-II'

For explanations see Figure 2 


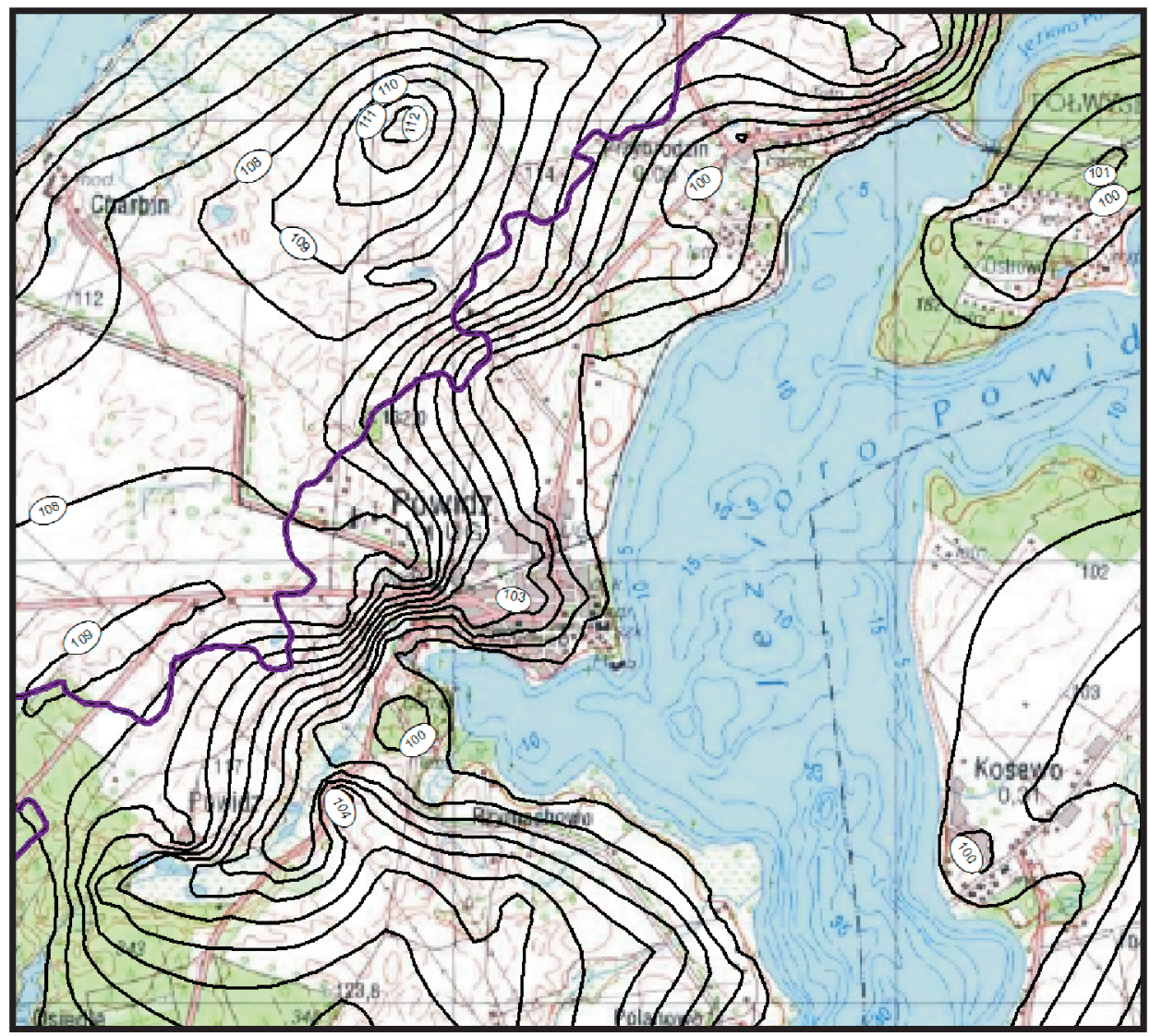

Fig. 4. Part of a map showing the distribution of hydroisohips of the first aquifer in the vicinity of Lake Powidzkie and its tributary, Struga Powidzka River - the state in 2012 (source Nowak, 2018)

The determination of hydrological and meteorological conditions used IMGW-PIB data resources. The data included water level gauge readings from lakes and rivers in the Gniezno Lakeland, and meteorological data from the nearest synoptic, climatological, and precipitation stations. Information on the climate and hydrology of the region analysed was supplemented with data from the KWB Konin measurement and observation network. Similarly to the hydrogeological data, characteristic monthly values were analysed. The collection of such information included observation sequences, usually going back several decades - the meteorological data covered the years 1961-2015, and most of the hydrological data covered the years 1993-2015.

The climatic and hydrological data obtained provided the basis for the preparation of water balances for selected lake catchments. They were used to assess the direction and volume of groundwater flow in the area of the lake basins in the years 2011-2015. The calculations employed the methodology proposed by Nowak (2018), based on the modified PenckOppokow equation [1], expressed in units of water column per unit of lake surface.

$$
P_{l}+D_{r}-E_{1}-H_{r}-H_{g v}+\Delta D H_{g}=R_{l}
$$

where: $P_{l}-$ real precipitation on the lake surface $\left[\mathrm{mm} ; \mathrm{m}^{3}\right] ; D_{r}-$ river inflow $\left[\mathrm{mm} ; \mathrm{m}^{3}\right] ; E_{l}-$ evaporation from the lake surface $\left[\mathrm{mm} ; \mathrm{m}^{3}\right] ; H_{r}$ - river outflow [mm; ${ }^{3}$ ]; $H_{g v}$ - groundwater runoff through the outflow valley $\left[\mathrm{mm} ; \mathrm{m}^{3}\right] ; \Delta D H_{g}$ - resultant of inflow and outflow of groundwater $\left[\mathrm{mm} ; \mathrm{m}^{3}\right] ; R_{I}$ - lake retention during the balance period $\left[\mathrm{mm} ; \mathrm{m}^{3}\right]$.
In equation [1], the elements providing water supply to the lake are: precipitation on the lake surface $\left(P_{l}\right)$, inflow from a river (tributary), and possible inflow from nearby lakes $\left(D_{r}\right)$ calculated from the flow rate curve prepared based on monthly hydrometric measurements and water gauge observations. The discharge elements include evaporation from the lake surface $\left(E_{l}\right)$, outflow via rivers $\left(H_{r}\right)$, calculated similarly as river inflow and groundwater runoff through the outflow valley $\left(\mathrm{H}_{\mathrm{gv}}\right)$, understood as groundwater flow in the river valley below the lake basin, or outflow towards the neighbouring lake located in the lower part of the tunnel valley. The $H_{g v}$ value was distinguished to show its substantial contribution in the vicinity of dammed lakes or lakes neighbouring each other where one of them is covered by the depression cone. The result of these elements is the retention of the lake $\left(R_{l}\right)$ determined based on real water level gauge readings on the lake. An unknown value in the formula is groundwater inflow and outflow, as well as hydraulic contacts of the lake basin with the surrounding aquifers. This is determined from the suggested formula [1] as the resultant value $\left(\Delta D H_{g}\right)$ of other known parameters.

A significant modification with reference to the current methodology is the fact that the lake surface area - taken into account in the determination of the amount of direct precipitation and evaporation from the water surface - was treated as a variable and calculated based on monthly averages of water levels. Lake surface areas at particular levels of the water table were determined based on an integrated land relief model considering the digital terrain model developed based on data from the LIDAR technology and previously digitised bathymetric plans of the 


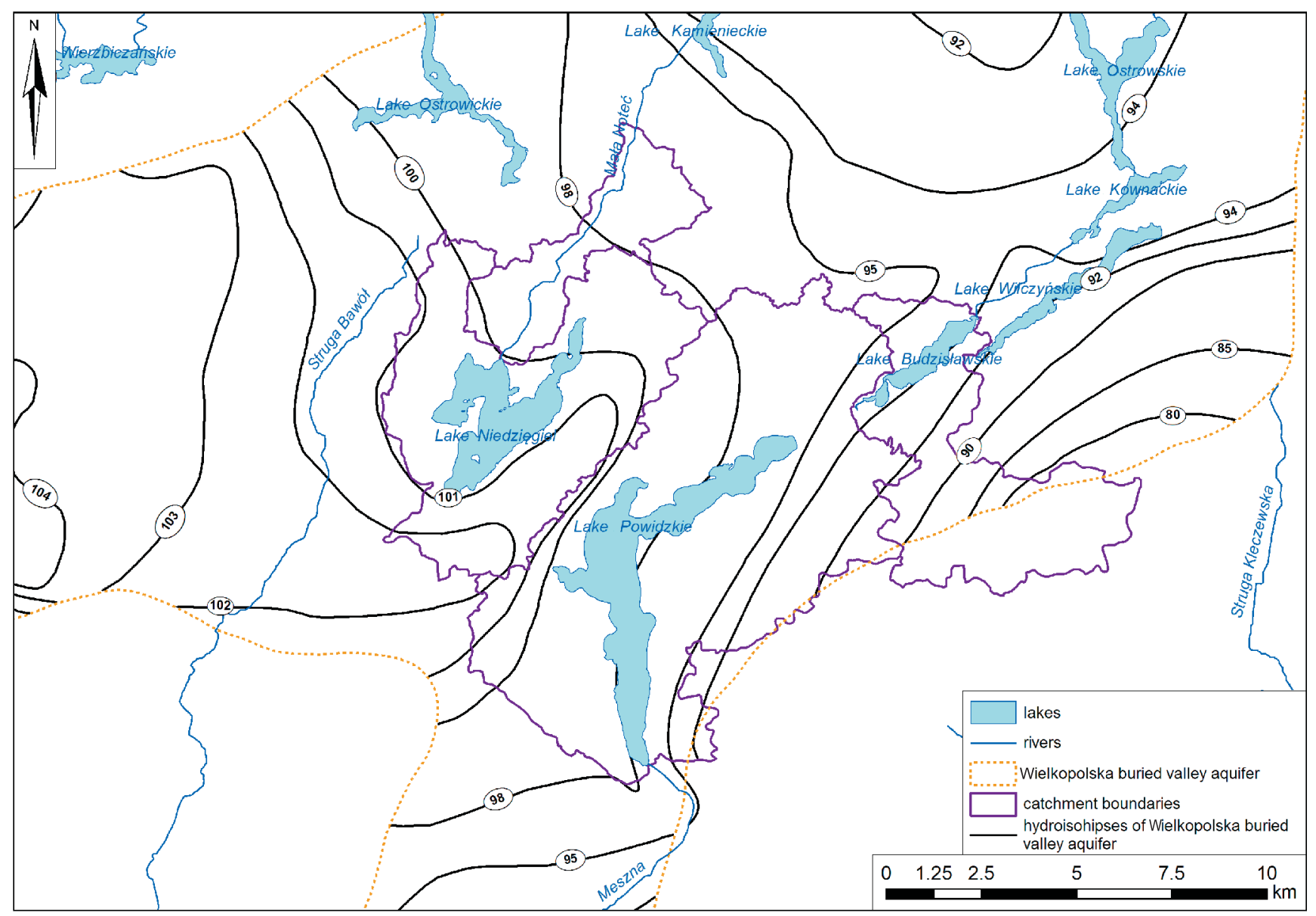

Fig. 5. Piezometric contour map of the Wielkopolska buried valley in the study area - the state in 2012 (source Nowak, 2018)

lakes. The methodology of the work is described (Nowak et al., 2018; Nowak and Lawniczak-Malinska, 2019).

Precipitation values were assumed based on meteorological data obtained from the IMGW-PIB and KWB Konin precipitation stations in the study area. The calculations employed precipitation values with corrections. This approach seems justified, because each measuring instrument is burdened with a measurement error affected by many factors. They were most comprehensively provided in studies made at the Hydrological Station in Radzyń, which repeatedly compared various methods of adjustment of precipitation measured at a height of $1 \mathrm{~m}$ in a Hellmann rain gauge - the basic tool for measuring precipitation amounts in the observation network of IMGW-PIB and many other institutions. The results of this work (Rösler and Chmal, 2010) permitted tracing the correction applied by other authors for different years and for different areas of Poland. The values vary between 18 and $55 \%$ in the winter half-year and $8-22 \%$ in the summer half-year. They are obviously highly variable. Based on the relative proximity of the study area to the location of the Hydrological Station in Radzyń, these data were used. The following corrections were applied in the calculation of precipitation: $20 \%$ for winter months (XII-II), $15 \%$ for spring (III-V) and autumn (IX-XI), and $10 \%$ for summer months (VI-VIII). The distribution of precipitation on lake surfaces was calculated for fields of $100 \times 100 \mathrm{~m}$, with interpolation of the corrected results from precipitation stations located closest to a given lake.
Based on data from the nearest climatological stations, evaporation from the water surface was calculated using Iwanow's (Kędziora, 2008) and Jaworski's (2004) equations [2] and [3] for the winter half-year.

$$
E=0.0018(t+25)^{2} \cdot(100-h)
$$

where: $E$ - monthly evaporation rate $[\mathrm{mm}] ; t$ - average monthly air temperature in the meteorological cage at a height of $2 \mathrm{~m}$ a.g.I. $\left[{ }^{\circ} \mathrm{C}\right]$; $h$ - average monthly relative air humidity [\%]; 0.0018 - value of the empirical coefficient expressed in units $\left[1 /\left({ }^{\circ} \mathrm{C} \%\right)\right]$.

$$
E_{0}=0.225\left(u_{2}+1\right)^{0.5} \cdot\left(e_{0 j}-e\right)
$$

where: $E_{0}$ - daily evaporation rate $[\mathrm{mm}] ; u_{2}$ - average daily wind speed at $2 \mathrm{~m}$ a.g.I. [m/s]; $e_{0 j}$ - average daily saturated water vapour pressure at lake surface temperature [hPa]; e - average daily value of water vapour pressure in the air in a meteorological cage at $2 \mathrm{~m}$ a.g.I. [hPa].

Based on the studies of Kędziora (2008, 2011), Chmal (2008) and Rösler et al. (2013), Ivanow's equation was chosen for periods with ice cover, and Jaworski's equation for winter months in which lakes were ice-free. The rules adopted required the determination of ice duration for the lakes being balanced. These were determined based on the list of water level observations for Lake Powidzkie, and field inspections of the re- 


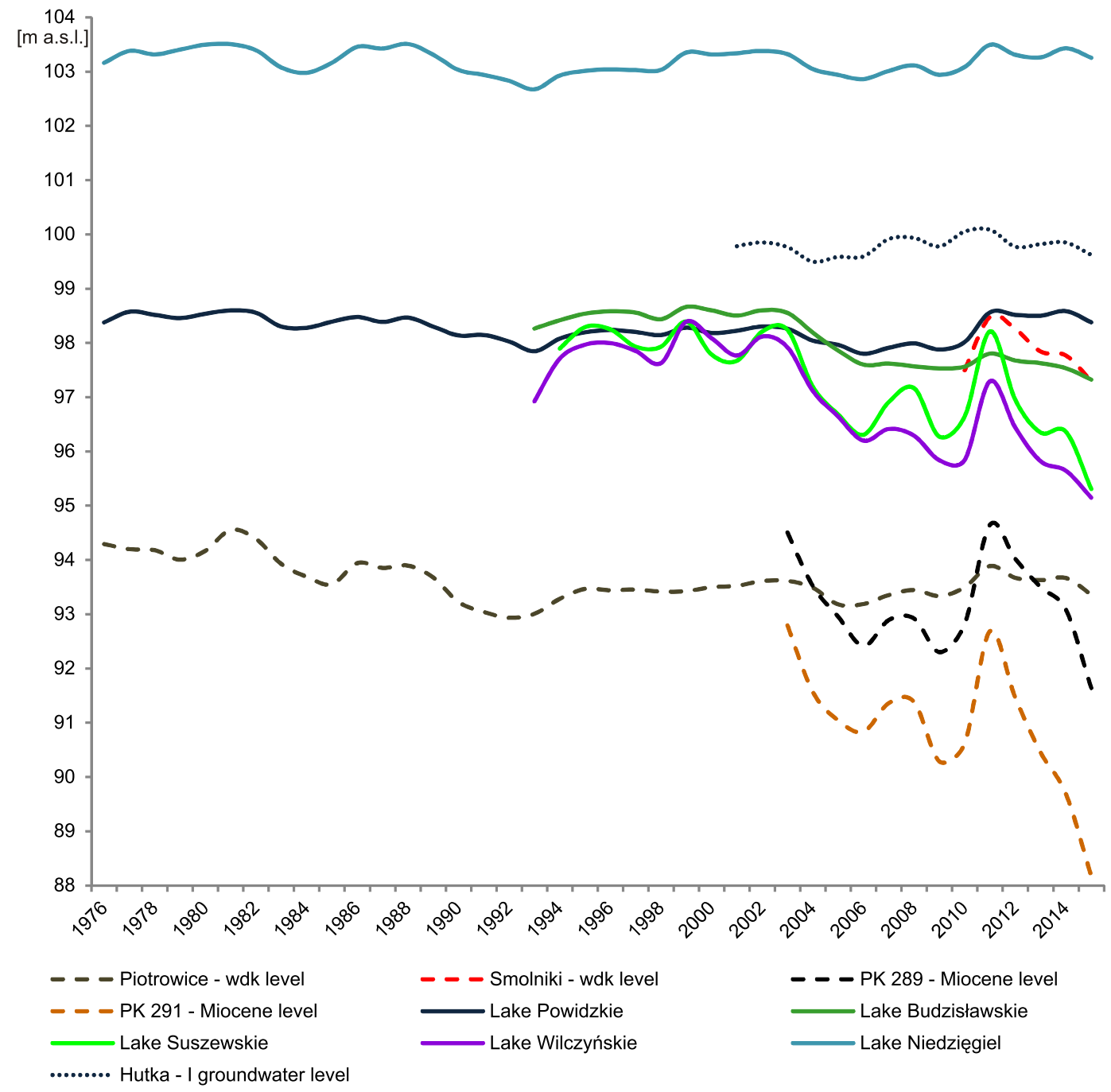

Fig. 6. Annual average surface water and groundwater levels in the study area (based on data from PIG-PIB, IMGW-PIB, LP, and the authors'research)

maining lakes. The calculations of evaporation for the summer half-year were based on data on evaporation from the free water area measured on evapometric rafts in Radzyń on Lake Sławskie (Sławskie Lakeland) and in Buntowo on Lake Sławianowskie (Krajeńskie Lakeland), the closest to the area analysed.

The inflow and outflow values of the river were obtained from measurements of the rivers' discharge in profiles at the inflows of lakes and in experimental catchments. Part of the data was taken from the IMGW-PIB resources, but most of them were obtained from our own measurements. The results of discharge measurements obtained for selected measurement profiles were then compared with water level lists for stations with local observations, and discharge curves were created. This permitted the determination of daily discharge values in the rivers. For watercourses without gauges, the hydrological analogue method was applied. Single measurements of flows from expedition profiles were compared to nearby measurement points with determined discharge curves. Based on these comparisons, additional analysis of specific discharges from the area studied, and the amount of precipita- tion preceding the field measurements, it was possible to determine the characteristic values of monthly flow for all the river measurement profiles.

Groundwater runoff through the outflow valley was calculated by means of Darcy's equation [4], after drawing cross-sections in the outflow valleys of the lakes, and taking measurements of the slope of the water table in the watercourse at the water gauge stations or in limnimetric wells. Water table measurements in the selected river section and in nearby lakes permitted the determination of the slope of the groundwater table within the aquifer in the river valley draining the lake, or within the morphological barriers separating lake basins located within the same glacial tunnel valley. This assumption seems justified, because research on the location of groundwater table at the boundaries of the stream valley and tunnel valleys showed that they corresponded with the surface water table values at these locations. The thickness of the aquifer was determined based on archives of boreholes drilled in the vicinity. The filtration coefficient values were determined based on control boreholes and laboratory analyses of sediment samples collected in the study area. The filtration coefficient value adopted was the averaged 
result of analyses conducted in 2-3 profiles along the section of the glacial valley/channel analysed in the calculations. The following equation was used:

$$
Q_{d w}=k \cdot l \cdot F
$$

where: $Q_{d w}$ - runoff through the outflow valley $\left[\mathrm{m}^{3}\right] ; k$ - permeability coefficient $[\mathrm{m} / \mathrm{s}] ; I-$ hydraulic gradient; $F$ - cross-sectional area of the outflow valley $\left[\mathrm{m}^{2}\right]$.

The balance involved the calculation of the sum of outflows and inflows as well as the retention of the lake on a monthly basis. This permitted the determination of periods in which the lake was recharged or drained by groundwater.

\section{RESULTS}

Hydrogeological cross-sections and numerical structural maps of aquifers with fitted models of lake basins permitted the determination of potential hydraulic contact zones of lakes and groundwater in the study area. Based on the above and on available studies (Przybyłek and Nowak, 2011; Jamorska, 2015; Nowak, 2018), all the lakes studied were found to be in contact with the groundwater of the first aquifer, with most of them additionally in contact with groundwater of the top inter-till aquifer (Fig. 7). The deepest lakes are in contact with the middle inter-till level and/or the level of the wdk, either directly or through that deposits underlie them (Fig. 7). Direct contact with the wdk level was documented in the deepest parts of Lake Powidzkie and elsewhere. In the area of Lake Suszewskie, a hydrogeological window was found, enabling water flow between the lake and deeper aquifers (Fig. 8).

In the case of connections with shallow aquifers, groundwater recharge of the lakes prevails. This is also suggested by the piezometric contours of the groundwater level near the lake basins. This phenomenon is also indicated by discharge measurements in the watercourses recharging the lakes, as well as by seepages and bog-springs observed on the slopes of lake tunnels and river valleys. Nonetheless, observations of the groundwater table near the lakes along with water balances for selected lake catchments show that in some parts of the coastal areas, under certain environmental conditions, the groundwater flow direction near the lakes may change (Fig. 9A-C). This situation usually occurs in the area of flat shores overgrown with vegetation during hot and dry periods. In such areas, evapotranspiration is higher than average, leading to a significant loss of groundwater. Such losses are too high to be compensated for by the inflow of groundwater from the edges of the lake tunnels, and the groundwater must be recharged by infiltration of lake water. This phenomenon was observed near the following lakes: Powidzkie, Powidzkie Małe, Niedzięgiel, Kańskie, and Słowikowo. As for the last of these lakes, evidence of seasonal changes in the direction of groundwater flow in the lake catchment is provided by the water balance prepared for the basin. The lake is very shallow and surrounded by an extensive belt of reeds and woody and bushy vegetation several times larger than the surface of the lake itself. Figure $9 \mathrm{C}$ shows changes in the elements of the water balance of Lake Stowikowo - it clearly shows how the share of recharge by groundwater changes over the hydrological year. It shows the highest values in the spring period, after melting, and systematically decreases with the development of vegetation. Negative values, suggesting groundwater discharge, reach their maximum in rain-free months at the end of summer, when the catchment is dry, and the growing season is at its peak. This phenomenon intensifies with an increase in the area of reeds and coastal vegetation (Nowak, 2010; Rösler et al., 2013). It is worth emphasising that a decrease in the water table in lakes over the last 30 years was accompanied by an increase in the share of hygrophilic plant groups in the littoral zone of the lakes analysed (Nowak et al., 2011; Nowak, 2018; Nowak and Lawniczak-Malinska, 2019). Combined with the observed increase in temperature in the area (Kędziora, 2008; Nowak, 2018), this results in an increased share of evaporation in the drainage of the lakes.

Water outflow from the lakes towards aquifers, at least in selected parts of the catchment, was also observed in the north-eastern part of the Powidzki Landscape Park, in lakes Suszewskie, Wilczyńskie, Budzisławskie, and Kownackie. As a result of the expanding range of the depression cone, connected with the drainage of lignite opencast mines located to the east, and because of the existence of a hydrogeological window in Lake Suszewskie (Fig. 8), the surface water and groundwater table has been decreasing in the area over the last 10 years, reaching $6.0 \mathrm{~m}$ (Fig. 6). In the case of Lake Suszewskie and Lake Wilczyńskie, there is no direct contact with the dewatering Miocene aquifer, but in the vicinity of these lakes, the adjacent aquifers connect with each other, which means that there is little isolation from the dewatering aquifer. Lake Budzisławskie, despite being deeper, does not cut the till layer and water loss from the lake should be associated with the outflow of water towards Lake Suszewskie through the groundwater aquifer and the first inter-till aquifer.

This has resulted in a disturbance of the natural water circulation pattern in which groundwater was drained by lakes. The situation currently occurs only in some parts of the catchment areas of these lakes, and largely depends on the amount of precipitation. In humid years, groundwater recharge from lakes increases, because infiltrating precipitation covers the water demand of plants and compensates for the loss caused by water outflow towards lower aquifers. In dry periods, when evapotranspiration significantly exceeds the amount of precipitation, the loss of groundwater caused by its seepage to lower aquifers results in a significant reduction of lake recharge, or even leads to a change in the direction of water flow in the contact zone of the lake and water in the first aquifer. As a result, water is drained from the lake. This phenomenon was documented in the years 2011-2015, when the area transitioned from the state of maximum filling of lakes and the surrounding aquifers - associated with exceptionally high rainfall in the 2010/2011 winter season (Nowak, 2018; Nowak and Ptak, 2019) - to the state of the extreme hydrological and hydrogeological low-water period in the autumn of 2015. The greatest water loss was then observed in Lake Suszewskie (Fig. 6) which - although it is neither the deepest lake nor nearest to the dewatered opencast mine has connections with the dewatered aquifer through a closely adjacent hydrogeological window. The drop in the water level of Lake Suszewskie affected the neighbouring lakes, located in the same tunnel valley and developing a system of connected basins due to the aggregated groundwater level and top inter-till level in this region. As a result, these lakes in the narrow zones separating them from Lake Suszewskie began to be drained by the groundwater level. This pattern of impacts is supported by observations of the water tables of these lakes and groundwater levels in their vicinity (Fig. 6), and by the water balances of lakes in the area (Fig. 9B).

In the case of hydraulic connections of lakes with deeper aquifers, as already mentioned above, the aquifer of the wdk was shown to be incised by the basin of Lake Powidzkie (Fig. 8). Indirect evidence, suggesting the hydraulic connection of the lake with the wdk, is provided by the piezometric contours of this 

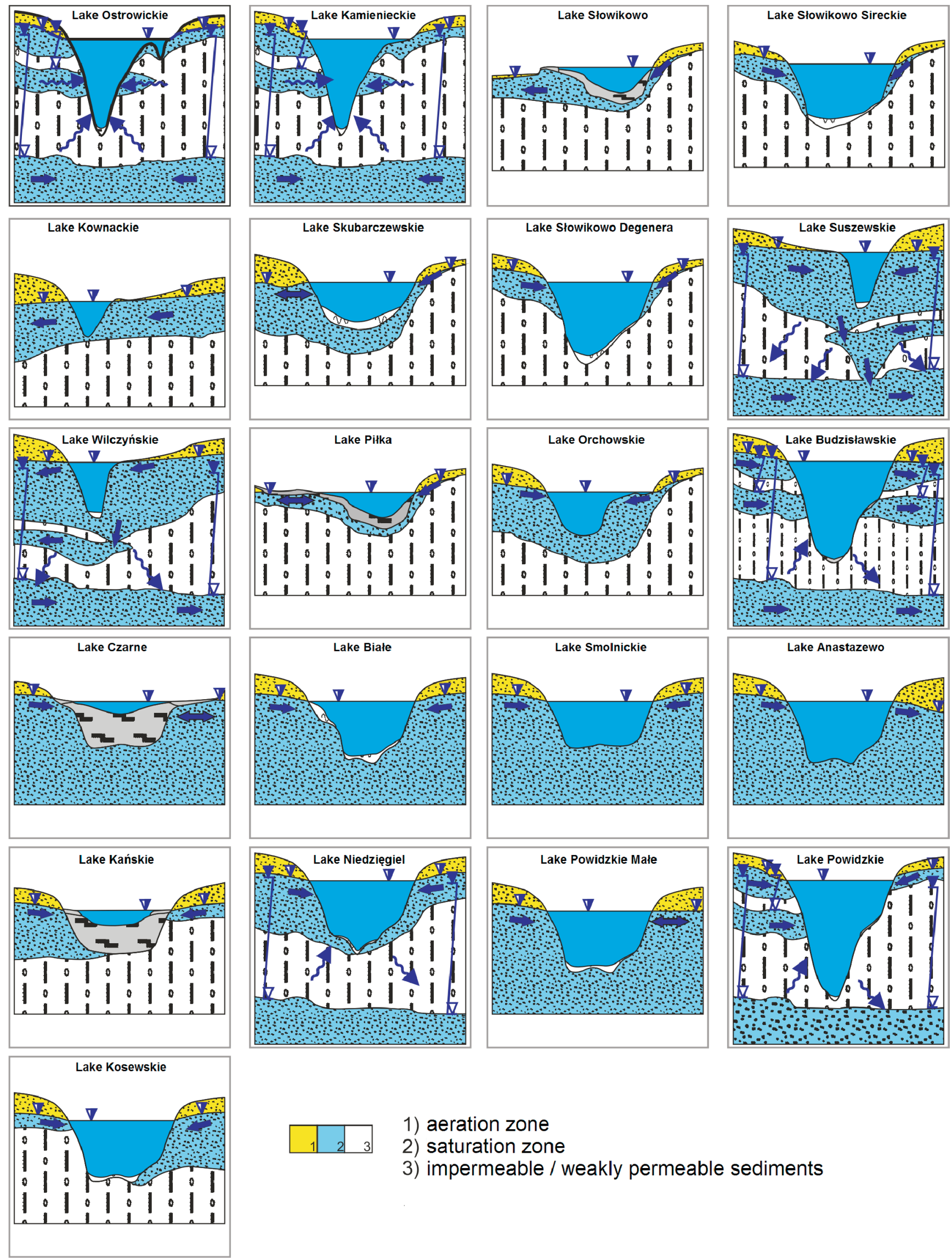

1) aeration zone

imparation zone

3) impermeable / weakly permeable sediments

Fig. 7. Contacts of lakes and groundwater in the study area (source Nowak, 2018, slightly modified) 


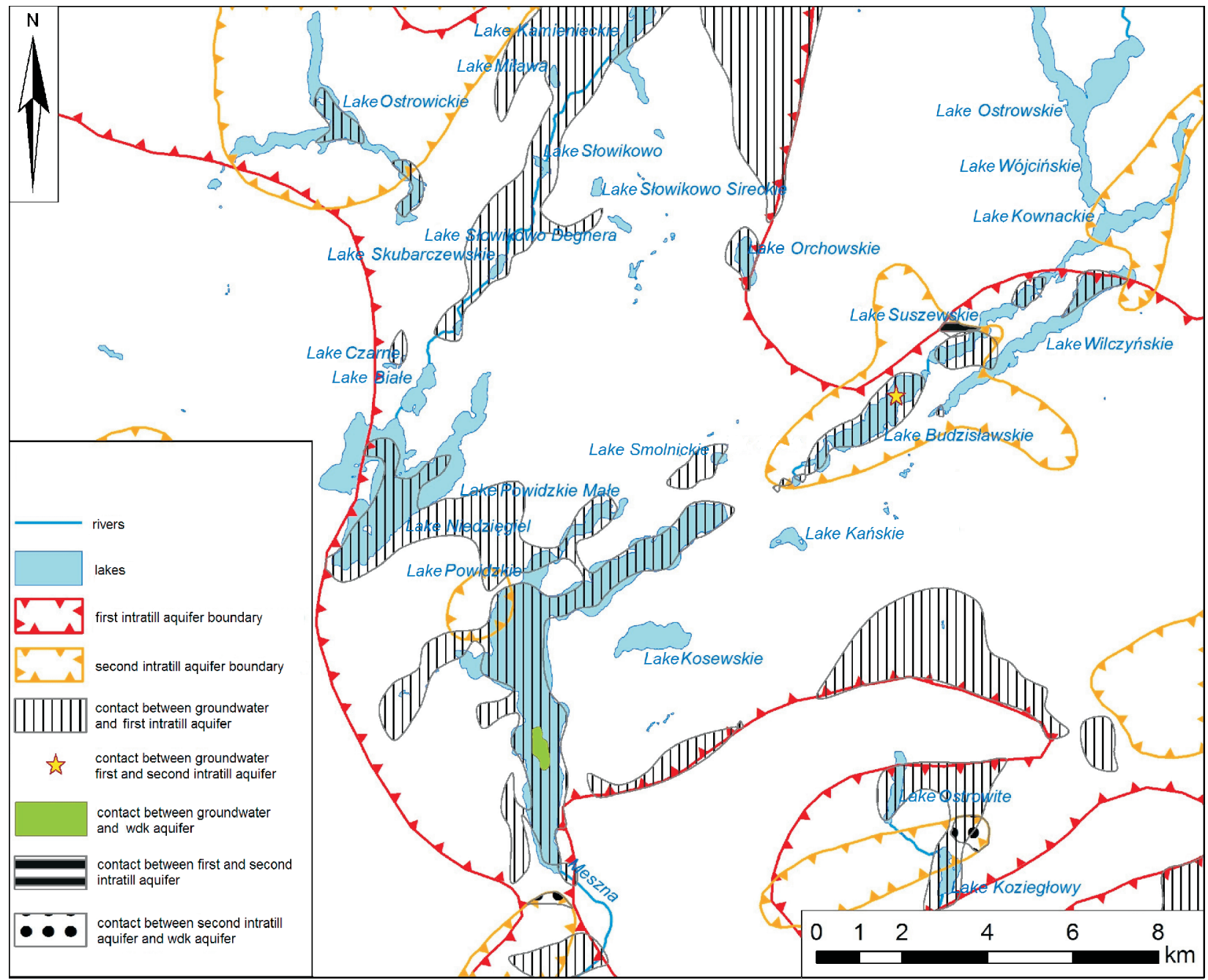

Fig. 8. Hydraulic contacts of aquifers in the study area (source Nowak, 2018)

aquifer (Fig. 5) which in the area of Lake Powidzkie show values corresponding to the altitude of its water table. This is also consistent with water level measurements carried out at the closed groundwater intake at Przybrodzin ( $50 \mathrm{~m}$ from the lake shoreline), and in the Ostrowo research well-located on the peninsula between lakes Powidzkie and Powidzkie Małe. The measurement results were compared with water levels in Lake Powidzkie. In the case of 5 measurement series carried out during this research period, the levels at all points did not deviate by $>10 \mathrm{~cm}$ from each other.

The slope of the water table in the wdk level in the area of Lake Powidzkie runs from west to east (Fig. 5), resulting in the lake being recharged from the west by this aquifer, and drained by it in the east. Due to the small size of the total catchment area and large volume of Lake Powidzkie, the lake is highly dependent on the resources of the wdk. In previous years, the lake together with the Meszna River Valley constituted a regional drainage base for this aquifer structure (Dabrowski, 1990; Nowak, 2018). As a result of mining drainage, the eastern part of the lake catchment was included in the drainage system associated with the depression cone of the nearby lignite opencast mines (Przybyłek and Nowak, 2011; Nowak, 2018). As a result of this situation, the lake is currently recharged from the wdk level only from the west, and is drained in its eastern part
(Fig. 5). A similar situation occurred in the area of Lake Budzisławskie, although it was intensified there by additional water outflow towards Lake Suszewskie. Another lake with a similar interaction pattern in the Park is Lake Ostrowickie. Its water level correlates with the location of the wdk groundwater level in its vicinity (Fig. 7). These lakes also have a similar amplitude of water level fluctuations as has the observed wdk level. The hydrological low-water periods and high lake water levels are evidently in line with the fluctuations of the wdk in the area (Fig. 6). Poor renewability of this aquifer's resources and the regional tendency to decrease its resources (Nowak, 2018) result in significant water loss in the deepest lakes of the Powidzki Landscape Park.

The exploitation of groundwater for municipal and agricultural purposes also plays an important role in the development of water interactions in the study area. The impact of groundwater intakes is much smaller than that of drainage associated with the lignite opencast mines, although it should not be disregarded. Their impact particularly intensifies in summer, when groundwater intake in the region significantly increases, in particular resulting from building development in areas adjacent to the lakes, and inflow of tourists and seasonal residents (Nowak, 2018, 2019; Nowak and Ptak, 2019). According to the exploitation logs of wells supplying water supply systems in the Powidz, 

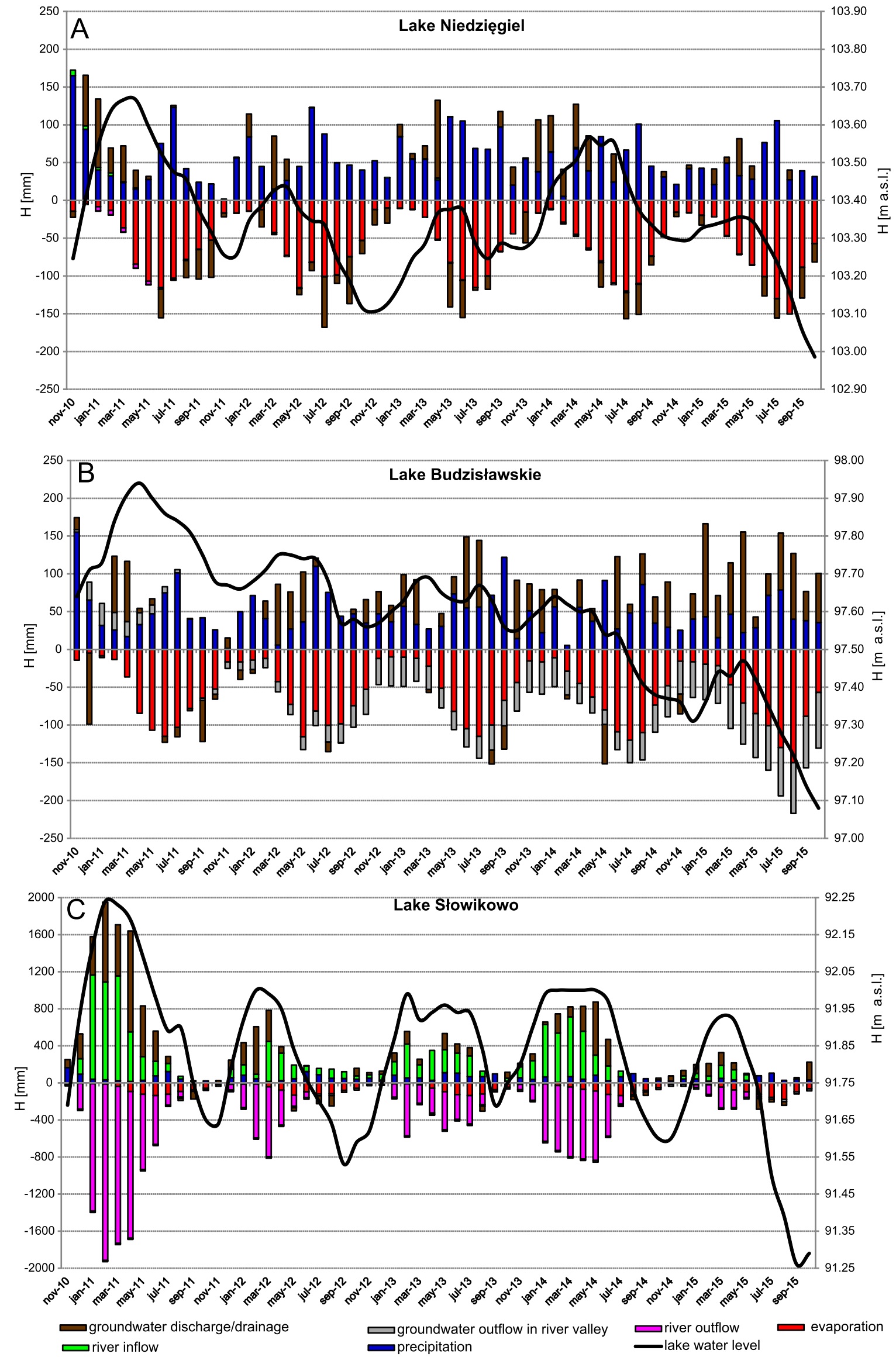

Fig. 9. Components of the water balance of selected lakes of the Powidzki Landscape Park in the years 2011-2015 (based on Nowak, 2018) 
Ostrowite and Orchowo communes, the consumption of groundwater in the catchment of the lakes studied increased with increase in the number of seasonal inhabitants. By comparison with the winter and summer months in holiday resorts, the increase reached $300-400 \%$ (Fig. 10). Moreover, private intakes function, usually not monitored and not subject to any operational control. They all result in additional reduction of groundwater resources in the region analysed, and therefore in reduction of the size of the stream feeding the lakes. They are particularly important in the eastern part of the area described, located within a depression cone associated with drainage of the lignite opencast mines. Local depression cones associated with municipal and economic water intakes in the region further intensify the effect of the mine depression cone.

Another factor of anthropogenic pressure leading to the impoverishment of water resources in the catchments analysed is diversion of water originating from mining drainage systems and sewage treatment plants in the surrounding communes. Mine waters which should normally recharge lakes from the eastern part of the discussed area are discharged to the Struga Kleczewska River, located in a different catchment system. A similar situation occurs in the case of sewage treatment plants supporting the Powidz, Kleczew, and Ostrowite communes. Purified water is channelled accordingly to the Struga Bawół, Struga Kleczewska and Struga Biskupia rivers (Fig. 11) and are therefore permanently lost from lake catchments.

The example of the Powidzki Landscape Park involves one more anthropogenic factor modifying the direction and flow of groundwater in the area of the lakes. Damming of a lake leads directly to an increase in the water level of the lake itself and in its vicinity. Depending on the type of soil surrounding the lake, the thickness of the aquifer, shape of the groundwater table, and dammed water column, this rise may impact across dis- tances of several hundred metres to several kilometres. The area covered by the damming effect experiences an evident increase in the amount of static groundwater resources. Such an effect was observed in the area of Lake Suszewskie. Its dammed-up water was recharging lakes including Lake Budzisławskie (Fig. 9B). The high water table in the lake caused by damming, while maintaining the same reference level in the higher elevated zones, also results in a decrease in the hydraulic slope, and consequently in a slowdown of groundwater recharge to the lake.

The persistent higher water level in the lake and in the associated upper aquifer with a low rise at deeper levels leads to a significant increase in water seepage towards the lower layers. Such a process is observed for the example in Lake Powidzkie and its surroundings. The lake has been being dammed for many years, but at the end of 2010 the valve regulating the outflow from the lake was rebuilt, resulting in a change in the water management procedures at the facility. The commissioning of the new valve coincided with very high rainfall in the study area (Nowak, 2018; Nowak and Ptak, 2018). As a result, the lake water level increased very rapidly, and over the next several years, despite the occurrence of dry years, it remained in the medium-high state. High precipitation in the winter season 2010/2011 also caused an increase in the groundwater level due to the isolation of deeper aquifers from the terrain surface (Figs. 2 and 3). The increase was not as rapid as in the nearby lake. As a result, at least temporarily, the direction of groundwater flow in the vicinity of the lake was reversed. For several months, groundwater was recharged from the lake both in its eastern and western parts. A similar situation concerned other dammed lakes: Ostrowickie, Niedzięgiel, and Suszewskie. In those cases, the lakes significantly contributed to the restoration of deep aquifers.

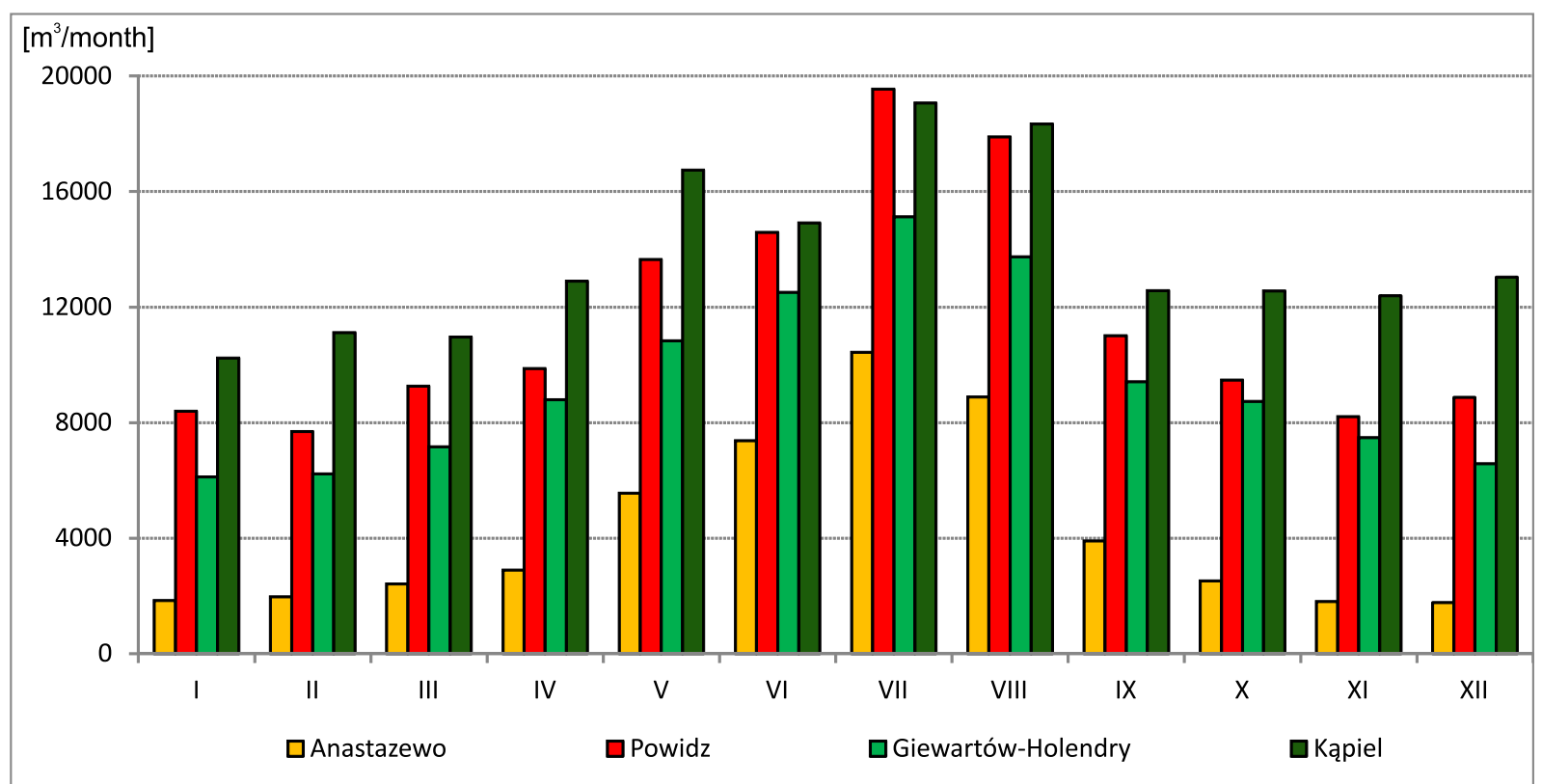

Fig. 10. Average monthly water consumption from groundwater intakes in the vicinity of Lake Powidzkie (based on Nowak, 2018) 




Fig. 11. Water and sewage management in the Powidzki Landscape Park (Nowak, 2018)

\section{CONCLUSIONS}

The results of this study show that the lakes of the Powidzki Landscape Park are the primary drainage bases for groundwater. In selected cases, particularly within areas with anthropogenic disturbances, they may also constitute a recharge zone, especially for largely exploited, deep, and poorly renewable aquifers.

Depending on the size and depth of the lakes in the study area, they are of local, transitional, or regional importance for aquifers. The deeper and larger the lake, the wider its impact. The example of the lakes discussed shows that small and shallow lakes usually drain the first aquifer with a small extent. The boundaries of the area usually coincide with, or only slightly exceed, the direct surface catchment of the lake. Deeper lakes in hydraulic contact with deep aquifers drain areas far beyond their catchment area, often exceeding the surface watershed. This is the case for lakes Powidzkie, Ostrowickie, and Budzisławskie. Their water levels largely depend on the location of the groundwater level in major aquifers of regional importance. This is reflected in the prolongation of the period of low lake water levels compared to shallower lakes in the vicinity affected by the same meteorological factors.

In exceptional situations, lakes constitute a water reservoir for deeper aquifers and for adjacent areas recharged with groundwater under normal conditions. The former was ob- served in the case of lakes with flat wide shores overgrown with water-consuming vegetation. In such zones with very high evapotranspiration, during hot and dry periods, the groundwater flow direction is reversed, and the areas receive water primarily from the lake. In the latter case, the deeper aquifer in contact with the lake has a reduced hydrostatic pressure, and its water level is lower than the lake water level. Such conditions were found primarily in the northeastern part of the Park near lakes: Budzisławskie, Wilczyńskie, and Suszewskie with catchments located in the depression cone of the Jóźwin II B lignite opencast mine. As a consequence, in the zone of hydraulic contact between the lakes and the drained aquifer, the direction of groundwater flow has been reversed, and water from the lake is currently seeping into the aquifer which is being drained. A similar situation was observed in the case of lakes Powidzkie, Ostrowickie, and Niedzięgiel, although in their case a part of the former recharge area was excluded. Here, an increase in recharge of water accumulated in the lake basin to lower aquifers is additionally intensified by their damming.

As a result of such close hydraulic contacts with deeper aquifers, showing an evident tendency for decreasing water levels, deep lakes from the study area show very high water loss and low capacity to rebuild these resources. Some of the shallow lakes located in the same tunnel valleys as the deep and large lakes respond in a similar way. 
Acknowledgements. The research was financed with the support of funds from the research project of the National Science Centre for young scientists who start their studies and do not have a PhD degree - PRELUDIUM. "Role of lakes in shaping groundwater recharge and drainage in the young glacial area in natural conditions and hydrodynamic anthropopressure" (contract no: UMO-2011/03/N/ST10/05014), con- ducted in the period 2012-2015, and from the system project "Scholarship support for doctoral students in faculties considered strategic from the point of view of Greater Poland's development", Submeasure 8.2.2 of the Human Capital Operational Programme - 2012/2013 edition.

\section{REFERENCES}

Bajkiewicz-Grabowska, E., 1982. The water exchange in the Wigry Lake Basins (in Polish with English summary). Przegląd Geofizyczny, 35: 229-240.

Bajkiewicz-Grabowska, E., 2002. Obieg materii w systemach rzeczno-jeziornych (in Polish). Wydawnictwo UW.

Brock, T.D., Lee, D.R., Janes, D., Winek, D., 1982. Groundwater seepage as a nutrient source to a drainage lake; Lake Mendota, Wisconsin. Water Research, 16: 1255-1263.

Burchardt, L., Przybyłek, J., 2004. Conditions of surface and groundwater flow vs. aquatic biocenoses of Lake Góreckie and Pond Pożegowo in the Wielkopolski National Park (in Polish with English summary). Morena, 11: 105-117.

Cheng, X., Anderson, M.P., 1993. Numerical simulation of ground-water interaction with lakes allowing for fluctuating lake levels. Ground Water, 31: 929-933.

Chmal, M., 2008. Methods of evaporation measurements from free water surface at meteorological station in Radzyń (in Polish with English summary). Wiadomości Meteorologii Hydrologii Gospodarki Wodnej, 52: 69-78.

Dabrowski, M., 2013. Uwarunkowania naturalne i antropogeniczne obiegu wody w Systemie Wielkich Jezior Mazurskich (in Polish). Wydawnictwo IMGW-PIB, Warszawa.

Dąbrowski, S., 1990. Hydrogeologia i warunki ochrony wód podziemnych Wielkopolskiej Doliny Kopalnej (in Polish). Wydawnictwo SGGW, Warszawa: 1-56.

Dabrowski, S., Rynarzewski, W., Straburzyńska-Janiszewska R., Zachaś, J., Pawlak, A., 2011. The groundwater resources of hydrogeological system in the eastern Wielkopolska Lake Region (in Polish with English summary). Biuletyn Państowego Instytutu Geologicznego, 445: 75-86.

Glazik, R., Gierszewski, P., 2001. Influence of groundwater intakes on water resources of the chosen lakes located within Gostynińsko-Włocławski Landscape Park. Limnological Review, 1: 95-102.

Ilnicki, P., 1996. Wpływ drenażu odkrywek węgla brunatnego na walory rekreacyjne Pojezierza Gnieźnieńskiego (in Polish). Aura, 11: 10-12.

Ilnicki, P., Górecki, K., Szczepański, M., 2017. Accelerated peatlands disappearance in the vicinity of the Konin brown coal strip mine. Journal of Water and Land Development, 35: 83-93.

Ilnicki, P., Orłowski, W., 2006. Klęska ekologiczna w Powidzkim Parku Krajobrazowym (in Polish). Aura, 10: 11-14.

Jamorska, I., 2015. Hydrogeological conditions of southern Kujawy region (in Polish with English summary). Przeglad Geologiczny, 63: 756-761.

Jaworski, J., 2004. Parowanie w cyklu hydrologicznym zlewni rzecznych (in Polish). Polskie Towarzystwo Geofizyczne, Warszawa.

Kędziora, A., 2008. Water balance of Konin strip mine landscape in changing climatic conditions (in Polish with English summary). Roczniki Gleboznawcze, 59: 104-118.

Kędziora, A., 2011. Climatic conditions and water balance of the Kujawy Lakeland (in Polish with English summary). Roczniki Gleboznawcze, 62: 189-203.

Kilkus, K., 1998. Hydrogeological approach in limnology (in Polish with English summary). In: Zagrożenia degradacyjne a ochrona jezior (eds. P. Lange and D. Borowiak): 51-59. Badania Limnologiczne, t. 1.

Krawiec, A., Śmietański, L., 2007. Groundwater flow system in Drawsko Lakeland (in Polish with English summary). Współczesne Problemy Hydrogeologii, 13, Wydawnictwo AGH, Kraków: 687-695.

Krygowski, B., 1954. Some remarks on the connection between the lakes of the Lowlands of Greater Poland and groundwater (in Polish with English summary). Przegląd Geograficzny, 26: 92-105.

Mikulski, Z., 1970. Shaping of the water balance of lakes in Poland (in Polish with English summary). Przegląd Geograficzny, 42: 433-447.

Nowak, B., 2010. Effect of rushes on evaporation rate in water reservoirs in the example of Powidzkie Lake. Limnological Review, 10: $37-41$.

Nowak, B., 2018. Rola jezior w kształtowaniu zasilania i drenażu wód podziemnych na Pojezierzu Gnieźnieńskim w warunkach naturalnych i antropopresji hydrodynamicznej (in Polish). Ph.D. thesis, Instytut Geologii UAM, Poznań.

Nowak, B., 2019. Reżim hydrologiczny Jeziora Powidzkiego oraz jego znaczenie w lokalnych i regionalnych systemach wodonośnych (in Polish). In: Jezioro Powidzkie wczoraj i dziś (ed. B. Nowak): 37-48. IMGW-PIB, Warszawa.

Nowak, B., Brodzińska, B., Gezella-Nowak, I., 2011. Natural and economic factors of shrinkage of lakes of the Wielkopolska Lakeland. Limnological Review, 11: 123-132.

Nowak, B., Lawniczak-Malinska, A.E., 2019. The influence of hydrometeorological conditions on changes in littoral and riparian vegetation of a meromictic lake in the last half-century. Water, 11: 2651.

Nowak, B., Nadolna, A., Stanek, P., 2018. Evaluation of the potential for the use of lakes in restoring water resources and flood protection, with the example of the Noteć Zachodnia River catchment (Gniezno Lakeland, Poland). Meteorology Hydrology and Water Management Research and Operational Applications. 6: 45-58.

Nowak, B., Przybyłek, J., 2008. Groundwater level oscillation in the Poznańskie Lake District during the last three decades and its impact on lakes on the example of Góreckie Lake. In: Anthropogenic and Natural Transformations of Lakes, vol. 2 (eds. E. Bajkiewicz-Grabowska and D. Borowiak): 135-137. Polskie Towarzystwo Limnologiczne, Gdańsk.

Nowak, B., Ptak, M., 2018. Effect of a water dam on Lake Powidzkie and its vicinity. Bulletin of Geography. Physical Geography Series, 15: 5-13.

Nowak, B., Ptak, M., 2019. Natural and anthropogenic conditions of water level fluctuations in lakes - Powidzkie Lake case study (Central-Western Poland). Journal of Water and Land Development, 40: 13-25.

Paczyński, B., Sadurski, A. ed., 2007. Hydrogeologia regionalna Polski, 1 (in Polish). Wydawnictwo PIG, Warszawa.

Pasławski, Z., 1975. Hydrological typology of lakes in Great Poland Lakeland (in Polish with English summary). Przegląd Geofizyczny, 20: 271-280. 
Pasławski, Z., Błaszczyk, B., 1970. Hydrologic characteristics and water balance of Lake Gopło (in Polish with English summary). Przegląd Geofizyczny, 23: 251-266.

Pomianowska, H., 2004. Modelling of groundwater flow of Chełmińskie Lakeland (in Polish with English summary). Acta Universitatis Wratislaviensis, 2729: 209-217.

Przybyłek, J., 2011. Groundwater conditions and problems of dewatering of lignite open pits in the eastern Wielkopolska area (in Polish with English summary). Roczniki Gleboznawcze, 62: 341-356.

Przybyłek, J., 2018. Current problems of the lignite opencast mines dewatering in the Wielkopolska region (in Polish with English summary). Górnictwo Odkrywkowe, 59: 5-14.

Przybyłek, J., Nowak, B., 2011. Impact of hydrogeological low flows and groundwater drainage by lignite open cast mine on aquifer systems of Gniezno Lakeland (in Polish with English summary). Biuletyn Państowego Instytutu Geologicznego, 445 513-527.

Rautio, A., Korkka-Niemi, K., 2015. Chemical and isotopic tracers indicating groundwater/surface-water interaction within a boreal lake catchment in Finland. Hydrogeology Journal, 23: 687-705.

Rösler, A., Chmal, M., 2008. Water balance of lake Sława (1976-2005). In: Anthropogenic and Natural Transformations of Lakes, vol. 2 (eds. E. Bajkiewicz-Grabowska and D. Borowiak): 161-165. Polskie Towarzystwo Limnologiczne, Gdańsk.

Rösler, A., Chmal, M., 2010. Korekta opadu w bilansie wodnym (in Polish). In: Dynamika procesów przyrodniczych w zlewni Drawy i Drawieńskim Parku Narodowym (eds. A. Grześkowiak and B. Nowak): 127-132. IMGW-Polskie Towarzystwo Geofizyczne, Poznań.

Rösler, A., Chmal, M., Chmal, T., 2013. Parowanie z powierzchni wody - porównanie wzorów z pomiarami (in Polish). Materiały konferencyjne XVII Ogólnopolskiej Konferencji Limnologicznej „Naturalne i antropogeniczne przemiany jezior”, Olsztyn-Ryn, 24-27.09.2013, UWM, Olsztyn: 68-70.

Rudnicki, S., Lewandowski, J., Nützmann, G., 2015. Investigating groundwater-lake interactions by hydraulic heads and a water balance. Groundwater, 53: 227-237.

Sacks, L.A., Swancar, A., Lee, T.M., 1998. Estimating ground-water exchange with lakes using water-budget and chemical mass-balance approaches for ten lakes in ridge areas of Polk and Highlands counties, Florida. US Geological Survey Water Resources Investigations Report: 98-4133.

Shaw, G.D., White, E.S., Gammons, C.H., 2013. Characterizing groundwater-lake interactions and its impact on lake water quality. Journal of Hydrology, 492: 69-78.

Stachowski, P., Oliskiewicz-Krzywicka, A., Kupiec, J.M., 2016. The natural characteristics of the state of the water in lakes in the area of Open Mine Quarry "Konin"(in Polish with English summary). Rocznik Ochrona Środowiska, 18: 642-669.

Su, X., Cui, G., Du, S., Yuan, W., Wang, H., 2016. Using multiple environmental methods to estimate groundwater discharge into an arid lake (Dakebo Lake, Inner Mongolia, China). Hydrogeology Journal, 24: 1707-1722. 